\title{
Factors Associated with Low Birth Weight in Horticulture Area, Semarang District, Indonesia
}

\author{
Nunik Triyani ${ }^{1}$, Onny Setiani ${ }^{2}$, Suhartono ${ }^{3}$
}

Department of Environmental Health, Public Health Faculty, Diponegoro University, Indonesia

\begin{abstract}
The use of pesticides in agricultural areas can have an impact on the condition of pregnant women and their fetuses, one of which is on LBW conditions. This study aims to proved the exposure of pesticides during pregnancy as a risk factor for the incidence of low birth weight babies (LBW) in Bandungan Sub district, Semarang District. Case group was defined as women giving birth to babies with LBW conditions. The control group defined as women who deliver babies without experiencing LBW conditions. Subject selection was limited to data in Bandungan sub district, Semarang District between 2017 and February 2019. The total sample for the case and control group was 104 respondents. This study used a case control method. Spraying pesticides activity $(O R=2,182 ; 95 \% C I=1,755-2,712)$, dan the use of pesticides $>4$ types $(O R=9,211 ; 95 \% C I=1,974-42,983)$ proved to be a risk factor for $L B W$ events.
\end{abstract}

Keywords-Pesticides exposure, low birth weight, women farmworker, risk factor.

\section{INTRODUCTION}

Pesticides have an important role in increasing agricultural production to ensure the availability of food. Farmers continue the usage of pesticides to produce large quantities of good quality agricultural commodities, but often do not follow the safety recommendations for use so that they can cause short-term adverse health effects such as rashes, blisters, blindness, nausea, dizziness, diarrhea, and death. ${ }^{1}$ The use of pesticides on women farmers who were in pregnancy was also feared to have an impact on the fetus such as spontaneous abortion, premature birth and low birth weight babies (LBW). ${ }^{2}$ Low birth weight babies (LBW) indicated as the babies born weighing at birth do not reach 2.5 kilograms. ${ }^{3} \mathrm{LBW}$ is one of the main factors in increasing mortality (mortality), morbidity (morbidity) and neonatal disability in infants, toddlers as well as children and causing prolonged effects on health. The incidence of LBW is one of the most calculated predictors related to infant mortality, especially in the first month of the birth of a baby. In addition, the incidence of infants with LBW will have an impact on the health of the newborn and also on the future development of the baby. ${ }^{4}$

Factors causing LBW condition originating from the women can be seen from the history of maternal diseases during pregnancy such as hypertension, heart, lung, and infectious diseases. While the factors originating from the fetus itself caused by multiple pregnancy, chromosomal abnormalities and the condition of the amount of amniotic water that exceeds normal limits (poly hydramnios). Besides these two factors, there were also other factors that cause LBW events, namely environmental factors. One trigger for LBW conditions influenced by environmental factors such as exposure to toxic substances. ${ }^{4}$ Women involvement in agricultural activities such as spraying and mixing several types of pesticides allows exposure to and poisoning because pesticides enter the body through inhalation and skin contamination. $^{5}$

One of the areas that become agricultural centers in Semarang District was Bandungan sub district. This research conducted in the area of horticulture in Bandungan sub district, Semarang District, Central Java, with agricultural products including flowers, vegetables and fruit. The highest production of ornamental plants or flowers in Bandungan sub district compared to two other sub districts namely Sumowono and Ambarawa. Data from the Duren Community Health Center in the sub district of Bandungan, Semarang District covering the working areas of the Bandungan, Banyukuning, Candi, Duren, and Kenteng villages, showed that there were $32 \mathrm{LBW}$ cases in 2015 then decreased in 2016 to 20 but in 2017 there was an increase in cases of as many as 26 people and in 2018 there were 30 cases. The active involvement of women in agricultural activities such as mixing pesticides and spraying plants has the potential to be exposed to pesticide exposure to the impact on reproductive health which can cause babies born with LBW conditions.

This study aims to prove the exposure of pesticides during pregnancy as a risk factor for the incidence of low birth weight babies (LBW) in Bandungan sub district, Semarang District. 


\section{METHODS}

This study used a case control design. The data used in this study were years of service, agricultural activities, and the amount of pesticides. The types of agricultural activities carried out were planting, fertilizing, binding plants to fields, pulling grass, caring for plants, spraying plants, and harvesting plants.

In case-control studies, cases (groups of women who gave birth to babies with LBW conditions) were compared with controls (groups of women who delivered babies without experiencing LBW conditions) to the exposure to risk factors interviewed used questionnaires. The total sample for the case and control group was 104 respondents. The technique used in sampling was purposive sampling. Data analysis used chi-square continuity correction.

This research has passed the ethical approval from Health Research Ethics Commitee by Faculty of Public Health Diponegoro University number 215/EA/KEPKFKM/2019.

\section{RESULTS}

The average working period of the case group was 6 years and the control group was 5 years. $55.8 \%$ of the case group and $67.3 \%$ of the control group had $\leq 5$ years of service. Respondents with a work period of $>5$ years were mostly found in the case group $(44.2 \%)$ compared to respondents in the control group $(32.7 \%)$. Statistical test results showed that the value of $\mathrm{p}=0.314$, OR $=1.633$, and $95 \%$ CI $=0.736-3.662$ showed no relationship between work period and LBW events (Table 1).

The proportion of risky agricultural activities was greater in the case group $(63.5 \%)$ than the control group $(44.2 \%)$. Statistical test results showed that the value of $\mathrm{p}$ $=0.077, \mathrm{OR}=2.190$, and $95 \% \mathrm{CI}=0.998-4.807$ showed no relationship between agricultural activities with LBW events (Table 1).

About $63.5 \%$ in the case group and $50 \%$ in the control group did plant planting activities. As many $21.2 \%$ of the case group and $15.4 \%$ of the control group did the activities of fertilizing plants, $98.1 \%$ of the case group and $88.5 \%$ of the control group carried out plant binding activities on the field. The proportion of respondents who treated plants was greater in the case group (96.2\%) than in the control group (94.2\%). As many $100 \%$ of the case group and $96.2 \%$ of the control group were pulling grass. As many $15.4 \%$ of the case group and no control group sprayed the plants using pesticides. $90.4 \%$ of the case group and $84.6 \%$ of the control group harvested the plants.

From 7 (seven) types of agricultural activities carried out by respondents, there was 1 (one) activity related to
LBW incidents, spraying plants using pesticides. The proportion of respondents who sprayed plants using pesticides was greater in the case group (15.4\%) than in the control group $(0 \%)$. Statistical test results show that the value of $\mathrm{p}=0.01, \mathrm{OR}=2.182$, and $95 \% \mathrm{CI}=1.755-2.712$ shows that there was a relationship between the spraying plants using pesticides and the incidence of LBW. Spraying plants is proven to be a risk factor for LBW. The women farm worker who spray plants using pesticides have a risk of 2 (two) times greater to give birth to children with LBW than women farmers who do not spray plants using pesticides (Table 1).

The proportion of the use of pesticide amounts to more than 4 (four) mixed species was greater in the case group $(96.2 \%)$ than in the control group (73.1\%). Chi square test results showed there was a relationship between the amount of pesticides used with LBW events where the value of $\mathrm{p}=0.003, \mathrm{OR}=9.211$, and $95 \% \mathrm{CI}=1.974$ 42.983. The amount of pesticides used was proven to be a risk factor for LBW events. Farmer women who use> 4 types of pesticides have a 9 (nine) times greater risk for giving birth to children with LBW than women farmers who use $\leq 4$ types of pesticides (Table 1 ).

Table.1. Relationship of years of work, agricultural activities, and amount of pesticides to $L B W$ events

\begin{tabular}{|c|c|c|c|c|}
\hline \multirow[b]{2}{*}{ Variables } & \multicolumn{2}{|c|}{ Low Birth Weight (LBW) } & \multirow{2}{*}{$\begin{array}{c}P \\
\text { value }\end{array}$} & \multirow{2}{*}{$\begin{array}{c}\text { OR } \\
(95 \% \\
\text { CI })\end{array}$} \\
\hline & $\begin{array}{c}\text { Case } \\
(\mathrm{n}=52)\end{array}$ & $\begin{array}{c}\text { Control } \\
(\mathrm{n}=52)\end{array}$ & & \\
\hline $\begin{array}{l}\text { Duration of } \\
\text { works }\end{array}$ & $\begin{array}{c}6,08 \pm 3,819 \\
; 5(1-25)\end{array}$ & $\begin{array}{c}4,92 \pm 2,440 \\
; 5(1-11)\end{array}$ & & \\
\hline$>5$ years & $23(44,2 \%)$ & $17(32,7 \%)$ & 0,31 & 1,633 \\
\hline$\leq 5$ years & $29(55,8 \%)$ & $35(67,3 \%)$ & 4 & $(0,736-$ \\
\hline
\end{tabular}

Agriculture activity

$\begin{array}{lcccc}\text { Risk } & 33(63,5 \%) & 23(44,2 \%) & 0,07 & 2,190 \\ \text { No riks } & 19(36,5 \%) & 29(55,8 \%) & 7 & (0,998- \\ & & & & 4,807)\end{array}$

Types of agricultural activities

Planting

$\begin{array}{lllll}\text { Yes } & 33(63,5 \%) & 26(50 \%) & 0,23 & 1,737\end{array}$

No $\quad 19(36,5 \%) \quad 26(50 \% \quad 5 \quad(0,793-$

$3,803)$

Cultivate

plants

Yes $\quad 11(21,2 \%) \quad 8(15,4 \%) \quad 0,61 \quad 1,476$

No $\quad 41(78,8 \%) \quad 44(84,6 \%) \quad 2 \quad(0,540-$

$4,032)$

Bind the

plant to the

field

Yes $\quad 51(98,1 \%) \quad 46(88,5 \%) \quad 0,11 \quad 6,652$




\begin{tabular}{ccccc}
\hline \multirow{3}{*}{ Variables } & \multicolumn{2}{l}{ Low Birth Weight (LBW) } & & OR \\
\cline { 2 - 3 } & Case & Control & value & $(95 \%$ \\
& $(\mathrm{n}=52)$ & $(\mathrm{n}=52)$ & & $\mathrm{CI})$ \\
\cline { 2 - 3 } No & $1(1,9 \%)$ & $6(11,5 \%)$ & & $(0,772-$ \\
& & & & 57,348
\end{tabular}

Revoke the

grass

$\begin{array}{lcccc}\text { Yes } & 52(100 \%) & 50(96,2 \%) & 0,47 & 0,490 \\ \text { No } & 0 & 2(3,8 \%) & 5 & (0,402- \\ & & & & 0,597)\end{array}$

$\begin{array}{lcccc}\begin{array}{l}\text { Caring for } \\ \text { plants }\end{array} & & & & \\ \text { Yes } & 50(96,2 \%) & 49(94,2 \%) & 1,00 & 1,531 \\ \text { No } & 2(3,8 \%) & 3(5,8 \%) & 0 & (0,245- \\ & & & & 9,561)\end{array}$

Spraying

plants using

pesticides

$\begin{array}{lcccr}\text { Yes } & 8(15,4 \%) & 0 & 0,01 & 2,182 \\ \text { No } & 44(84,6 \%) & 52(100 \%) & & (1,755-\end{array}$

2,712)

Harvesting

plants

$\begin{array}{lcccc}\text { Yes } & 47(90,4 \%) & 44(84,6 \%) & 0,55 & 1,709 \\ \text { No } & 5(9,6 \%) & 8(15,4 \%) & 3 & (0,520- \\ & & & & 5,621)\end{array}$

The amount of

pesticides

\begin{tabular}{lcccc}
$>4$ types & $50(96,2 \%)$ & $38(73,1 \%)$ & 0,00 & 9,211 \\
of & & & 3 & $(1,974-$ \\
pesticide & & & 42,983 \\
$\mathrm{~S}$ & & & ) \\
$\leq 4$ types & $2(3,8 \%)$ & $14(26,9 \%)$ & & \\
of & & & \\
pesticide & & & \\
$\mathrm{S}$ & & & \\
\hline
\end{tabular}

\section{DISCUSSION}

Bandungan sub district was located in Semarang District, Central Java, which is at an altitude of $892-915$ meters above sea level with an area topography in the form of slopes or peaks so that the environmental conditions are suitable for horticultural farming. The air temperature in Semarang Bandungan sub district relatively cool. Bandungan sub district has a rainfall of 1,291 mm with 84 rainy days in 2017. The highest rainfall was from November to February. ${ }^{6}$

The average working period of the case group was 6 years and the control group was 5 years. About $55.8 \%$ of the case group and $67.3 \%$ of the control group had $\leq 5$ years of service. Respondents with a work period of $>5$ years were mostly found in the case group (44.2\%) compared to respondents in the control group (32.7\%). Statistical test results showed that the value of $\mathrm{p}=0.314$,
$\mathrm{OR}=1.633$, and 95\% $\mathrm{CI}=0.736-3.662$ showed no relationship between work period and LBW events.

Risky farming activities were not proven to be a risk factor for low birth weight babies (LBW) in Bandungan sub district, Semarang District. Spraying plants activity is proven to be a risk factor for the incidence of low birth weight babies (LBW) in Bandungan sub district. Risky agricultural activities was the result of accumulation of seven other types of agricultural activities. The seven agricultural activities include planting plants, fertilizing, binding plants to fields, pulling grass, caring for plants, spraying plants, and harvesting plants. Even though after categorizing, agricultural activities have proven to be unrelated and are not a risk factor for LBW events, there are types of spraying plants activities that are statistically significant for LBW. The results of a previous study conducted by Fatmawati (2016) showed that risky agricultural activities were associated with LBW events in Ngablak, Magelang ( $\mathrm{p}$ value $=0.014$ ). The involvement of pregnant women in agriculture consists of various types of work and some of them are directly involved with pesticides, which are activities when women prepare and mix pesticides or spray plants in the fields. ${ }^{7}$

The activity of spraying plants using pesticides was associated with LBW events because these activities have a very high likelihood of being exposed to pesticides. When pregnant women spray the plants, pesticides can enter the body through the respiratory system or skin abortion. Very small pesticide particle size can be inhaled and enter the bloodstream, so that it disrupts the health system of pregnant women and can have an impact on LBW.

The number of pesticides $>4$ types of pesticides was proven as a risk factor for the incidence of low birth weight babies (LBW) in Bandungan Sub district, Semarang District. The more the amount of pesticide mixture used to spray plants, the higher the likelihood of exposure to pesticides. The cumulative effect of pesticide toxicity caused by mixing several types of pesticides can cause damage to the body's systems. The mixed of pesticides usually became from the avermectin, carbamate, pyrethroid, and organophosphate classes. Though these pesticides have different toxicity mechanisms in the body. The avermectin pesticide acts by attacking the aminobutyric acid $\gamma$ (gamma) receptor. Organophosphate and carbamate pesticides work by inhibiting the enzyme cholinesterase. Pyrethroids work by attacking voltagegated sodium channels.

Pesticides can act as endocrine disruptors and the mechanism directly damage cellular structures, disrupt biochemical mechanisms in the body, and produce toxic 
metabolites. ${ }^{8}$ This condition can lead to various health problems, especially in vulnerable populations, namely pregnant women and infants.

\section{CONCLUSION}

Work period $\geq 5$ years was not proven as a risk factor for the incidence of low birth weight babies (LBW) in Bandungan Sub district, Semarang District. Risky farming activities were not proven to be a risk factor for the incidence of low birth weight babies (LBW) in Bandungan Sub district, Semarang District. Spraying pesticides activity was proven to be a risk factor for the incidence of low birth weight babies (LBW) in Bandungan Sub district. The number of pesticides $>4$ types of pesticides was proven as a risk factor for the incidence of low birth weight babies (LBW) in Bandungan sub district, Semarang District.

\section{REFERENCES}

[1] Jeyaratnam J. Acute pesticides poisoning: a major global health problem. World Heal Stat Q. 1990;14(3):139-44.

[2] Gracia A. Pesticide exposure and women's health. Am J Ind Med. 2003;44(6):589 - 594.

[3] World Health Organization(WHO). Low Birth Weight: Country, Regional and Global Estimates. Geneva, Switzerland; 2013.

[4] Dabrowski S, Wojciech H, Kinga P. Pesticides Exposure and Birth Weight: An Epidemiological study in Central Poland. Int J Occup Med Environ Health. 2013;16(1):31-9.

[5] Djojosumarto P. Teknik Aplikasi Pestisida Pertanian. Yogyakarta: Kanisius; 2008.

[6] Badan Pusat Statistik Kabupaten Semarang. Kabupaten Semarang Dalam Angka 2018. 2018.

[7] Fatmawati M, Windraswara R. Faktor Risiko Paparan Pestisida Selama Kehamilan Terhadap Kejadian BBLR Pada Petani Sayur. Unnes J Public Heal. 2016;5(4).

[8] Bretveld RW, Thomas CMG, Scheepers PTJ, Zielhuis GA, Roeleveld N. Pesticide exposure: the hormonal function of the female reproductive system disrupted? BioMed Cent. 2006;4(30):1-14. 